\title{
Radiation Therapy in Primary Non- Hodgkin's Lymphomas of the CNS
}

\author{
F. H. J. RAMPEN, * J. G. van ANDEL,* W. SIZOO† and J. A. M. van U.NIK+ \\ * Department of Radiotherapy, Rotterdam Radiotherapy Institute, Groene Hilledijk 301, 3075 EA Rotterdam, The \\ Netherlands \\ †Department of Hematology, Rotterdam Radiotherapy Institute, Groene Hilledijk 301, 3075 EA Rotterdam, The \\ Netherlands \\ ${ }_{+}^{+}$Pathologic Institute, Faculty of Medicine, University of Utrecht, Utrecht, The Netherlands
}

\begin{abstract}
Twelve patients with primary non-Hodgkin's lymphomas of the CNS are described. Out of 5 CSF cytologies performed, 4 were positive. Radiotherapy was given to the tumour area in 3 patients, or to the whole brain in 5 patients. Four cases received radiotherapy to the spinal cord as well. Patients receiving whole CNS irradiation, including the spinal cord, seem to have a longer survival than patients with brain irradiation only. Out of the 5 patients with total brain irradiation, 2 showed a relapse in the spinal cord. It is suggested that therapy should be given not only to the tumour bearing areas, but should comprise the entire CNS.
\end{abstract}

\section{INTRODUCTION}

PRIMARY non-Hodgkin's lymphomas of the central nervous system (CNS) are comparatively rare. Freeman et al. [1] reported an incidence of $1.6 \%$ of all primary, extranodal non-Hodgkin's lymphomas occurring in the brain or cord. Most of the discussions concerning the malignant lymphomas of the CNS have been confined to the clinical features or the histologic appearance of these tumours [24]. Only scanty information as to the exact treatment has been provided in the literature. The role of radiotherapy appears essential, though ill-defined [5-7]. Despite radiation therapy, most cases show a rapidly dismal outcome, mainly because of local recurrences. Survivals of 5 yr or more are very exceptional. This might be due to inadequate dosage schedules or to inappropriate field sizes.

In 1968, in the Rotterdam Radiotherapy Institute, therapy of the primary cerebral lymphomas was altered from irradiation of the tumour area to total skull irradiation, mainly because of poor treatment responses. Since the results of this new approach remained disappointing, in 1973 we commenced giving radiotherapy to the entire CNS, including the spinal cord. This report deals with the preliminary results in a limited number of cases.

Accepted 20 February 1979.

\section{MATERIALS AND METHODS}

From 1957-1976 sixteen patients were diagnosed with non-Hodgkin's lymphomas with initial presentation in the CNS. One of these cases had a spinal cord lesion of which the site of origin-intramedullary or extraduralcould not be established with certainty. This patient was excluded from the study. Screening for extraneural disease was not routinely performed before 1970 . Seven patients underwent complete staging procedures, including liver and spleen scans, lymphangiograms and bone marrow aspirates; partial staging was done in 2 cases. Three of these 9 patients evidenced nodal or visceral involvement. They were also excluded from the present series. Thus, 12 acceptable cases remained for study. In 2 instances autopsy was performed, without showing evidence of extraneural disease. Four patients had no screening or post-mortem examination; the survival period was 6, 7, 13 and 41 months without clinical evidence of spread beyond the CNS.

Diagnosis was confirmed at microscopy of biopsy specimens after gross removal of the tumour in 7 cases. All surgical procedures were incomplete. One patient underwent a decompression operation; diagnosis was confirmed at autopsy. In 4 instances cytologic examination of the cerebro-spinal fluid (CSF) revealed tumour cells consistent with non- 
Hodgkin's lymphoma. These patients had no surgical resection or biopsy of their tumours. Dexamethasone was administered in 5 cases for 1-2 months.

Until 1970 radiotherapy was given in most cases with orthovoltage. Later linear accelerators were introduced for the treatment of the CNS lymphomas. Radiotherapy was initiated within $1-4$ weeks after diagnosis. Brain irradiation was given through opposed lateral portals. For the irradiation of the spinal cord one posterior field was used; dosages were calculated at $5.5-6.5 \mathrm{~cm}$ depth. Figure 1 shows a schematic representation of the skull and spinal fields. Three patients received irradiation to the tumour area only. In 5 patients the entire skull was irradiated. In 4 instances radiotherapy was given to both the brain and cord.

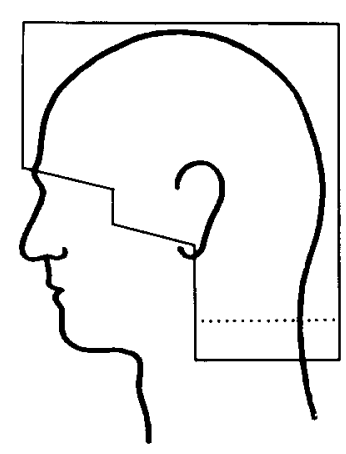

4,000-4,500 rad

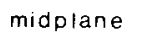

$4-4 \frac{1}{2} w k s$

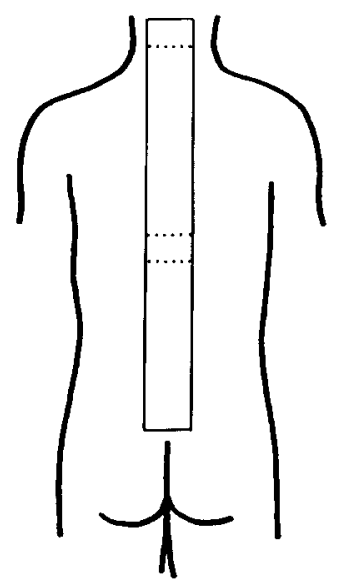

3,000-3,300 rad

at $\pm 6 \mathrm{~cm}$

$4-4 \frac{1}{2}$ wks
Fig. 1. Radiation fields and dosages for entire C. LS imadiatiun.

None of our cases had an associated immunological deficiency and there were no transplant recipients [8]. None of the patients received chemotherapeutic agents before or during their illness.

\section{RESULTS}

Table 1 summarizes the clinical, therapeutic and survival data of the 12 cases. Six of the patients were males and 6 females. The ages ranged from 31 to $71 \mathrm{yr}$. The mean age was 52 yr.
In 9 patients the duration of presenting symptoms before time of diagnosis was 12 months or less. In 3 cases the patient's history was unreliable. Table 2 illustrates the initial clinical signs and symptoms at the time of diagnosis. These findings have been arbitrarily grouped into 3 categories. Most cases exhibited a complexity of clinical features, comprising more than one category.

The topographic distribution of the lesions was of a diffuse or multifocal nature in 6 cases. Solitary foci in one of the lateral hemispheres were encountered in 4 patients. In 2 cases the brain stem was affected. No foci were seen in the cerebellum. Cytologic examination of the CSF was performed in 5 instances, with 4 positive results.

In 6 of 12 patients histology or cytology specimens were still available for reexamination according to the criteria of the Rappaport, Kiel and Lukes/Collins classifications [9-11]; they were all of the high-grade malignancy type (Table 3). 'The remaining 6 patients were classified at the time of diagnosis as "reticulum cell sarcoma" according to the old nomenclature.

The initial response after radiotherapy was reasonable to good and, in nearly all cases, cmbraced a marked improvement of neurological symptoms and of behaviour. One patient (No. 12) showed only slight improvement. Infection of the bone flap might have been a major factor contributing to the negligible response and the ultimate death in this case. There was no difference noted in the initial response between the patients who received dexamethasone and those who did not. Surgery did not influence the prognosis to any extent. As already stated, all surgical interventions were incomplete.

The site of the lesion possibly influences the prognosis. This becomes apparent if we divide our material - arbitrarily - into patients with a "favourable" and "unfavourable" localization. Unfavourable here means a diffuse or multifocal spread, or locations in the brain stem region with its vital structures and the high risk of direct tumour extension into the spinal cord. Patients with a positive CSF cytology are also grouped under this heading. Patients with a solitary focus in one of the lateral hemispheres and a negative, or unknown, CSF cytology are grouped under the favourable locations. Two of the 3 patients in the latter group survived more than $2 \mathrm{yr}$. Of the 9 patients in the first group 7 dicd within $2 \mathrm{yr}$.

The patient's sex also sh owed a correlation 
with prognosis. The 4 paticnts with a survival period of more than 24 months were all females. Since the available literature shows no indication of a substantial difference in survival between the two sexes, the discrepancy noticed in our series is probably fortuitous.

The radiotherapy modality was of prognostic importance (Table 4). After whole CNS irradiation survival was better than when only the tumour area or the brain was treated. All patients with radiotherapy to the entire CNS survived more than 1 yr. One patient is free of disease after $3 \mathrm{yr}$. The second patient went through a period of deterioration after 23 months, but responded fairly well to dexamethasone (post-radiation effect?); she is in a reasonable condition after 35 months, without further deterioration. The other 2 patients survived for 13 and 16 months respectively, the latter case being complicated by an infected bone flap, which probably accelerated the fatal outcome. The difference in survival between the patients with entire CNS irradiation and the partial treatment group becomes even more striking if one considers that all patients with total CNS irradiation had an unfavourable localization of their tumours (Table 5).

Most patients suffered a local, i.e. cerebral, recurrence of their lymphomas. However, 2 cases showed distinct features of a spinal cord relapse: case No. 7 had a recurrence in the spinal axis together with general disorientation, whereas case No. 8 showed a cord lesion as the first manifestation of CNS relapse. Both patients received radiotherapy to the brain only.

\section{DISGUSSION}

Brain involvement by non-Hodgkin's lymphomas of the CNS is usually more extensive than is indicated by the clinical signs and symptoms. Conventional investigations (electroencephalography, brain scans, angiography, etc.) are insufficiently precise to adcquately reveal the extent of the disease. Computer tomography of the brain might provide better information [12]. Several authors have stressed the diffuse spread of these tumours $[2,13,14]$. On microscopic examination perivascular cuffing and small tumour aggregates are often found remote from the primary tumour $[15,16]$. Subependymal and meningeal infiltrations are frequently encountered. In the study of Adams [13] diffuse in- filtration of the meninges was a prominent feature in 4 of 8 cases with primary cerebral lymphomas. Barnard and Scott [16] observed meningeal involvement in 11 out of $14 \mathrm{pa}$ tients, whereas all 14 cases showed subependymal condensations of tumour cells. Though clear leptomeningeal involvement was usually confined only to regions close to underlying infiltration, the same authors emphasize that in all their cases microscopy revealed diffuse parenchymal disease apart from any circumscribed tumour. This indicates that diffuse meningeal spread might be less rare than is generally believed. Furthermore, the frequent occurrence of perivascular coatings with tumour cells, i.e. infiltration of the VirchowRobin spaces, suggests that the risk of seedlings through the CFS is highly conceivable.

Although primary cord lesions of the CNS lymphomas are very rare, secondary involvement of the medulla oblongata or spinal cord after brain primaries is by no means unusual. This spread may occur through the CSF, whereas brain stem tumours may extend directly into the cord. Barnard and Scott [16] reported brain stem involvement in 11 out of 14 patients. Miller and Ramsden [17] gave a detailed report on spinal cord lesions at autopsy. These authors found among their series of 6 cases 4 who showed definite involvement of the spinal axis, whereas a fifth case exhibited tumour extension into the medulla oblongata but not beyond. Among 20 patients irradiated to the brain only, Sagerman et al. [5] described 6 patients who evidenced recurrences in the spinal canal. More recently, the case history of a 66-yr old woman with spinal cord relapse after brain irradiation was usefully discussed by Lehrich et al. [18]. Likewise, we observed 2 patients with relapses in the cord after irradiation of the skull only.

Cytologic examination of the CSF is not routinely performed in patients with space occupying masses in the brain. However, Jellinger et al. [6] considered CSF cytology as a useful and reliable tool for clinical diagnosis. Out of 40 C.SF's analysed 23 showed distinct pleocytosis, whereas 11 cases evidenced a positive cytology. Since the authors do not specify the number of CFS's subjected to cytological examination, the actual rate of positive results might have been considerably higher. In our series the CSF was examined in 5 cases, with 4 positive cytologies. Finally, the surgical (diagnostic) procedure, which usually precedes radiotherapeutic management, increases the risk of "spill" of tumour cells through the meningeal spaces. These 
Table 1. Summary of clinical, treatment and survival data

\begin{tabular}{|c|c|c|c|}
\hline Sex Age & Localization & $\begin{array}{c}\text { CSF } \\
\text { Cyytology }\end{array}$ & Radiotherapy \\
\hline $1 \mathrm{~F} 37$ & $\begin{array}{l}\text { Unifocal, } \\
\text { R-hemisphere }\end{array}$ & & $\begin{array}{l}\text { Tumour area } \\
1060 \mathrm{rad} / 6 \mathrm{wk} \\
250 \mathrm{kV}\end{array}$ \\
\hline $2 \mathrm{M} 54$ & Pons & & $\begin{array}{l}\text { Tumour area } \\
4000 \mathrm{rad} / 4 \mathrm{wk} \\
\text { Cobalt } 60\end{array}$ \\
\hline $3 \mathrm{M} 31$ & Brain stem & + & $\begin{array}{l}\text { Tumour area } \\
4000 \mathrm{rad} / 4 \frac{1}{2} \mathrm{wk} \\
250 \mathrm{kV}\end{array}$ \\
\hline $4 M 55$ & $\begin{array}{l}\text { Diffuse, } \\
\text { including brain stem }\end{array}$ & & $\begin{array}{l}\text { Total brain } \\
4060 \mathrm{rad} / 6 \frac{1}{2} \mathrm{wk} \\
250 \mathrm{kV}\end{array}$ \\
\hline 5 F 45 & Multiple & - & $\begin{array}{l}\text { Total brain } \\
4000 \mathrm{rad} / 5 \mathrm{wk} \\
250 \mathrm{kV}\end{array}$ \\
\hline $6 \mathrm{M} 67$ & $\begin{array}{l}\text { Unifocal, } \\
\text { frontal }\end{array}$ & & $\begin{array}{l}\text { Total brain } \\
4000 \mathrm{rad} / 4 \mathrm{wk} \\
6 \mathrm{mV}\end{array}$ \\
\hline $7 \mathrm{~F} 71$ & $\begin{array}{l}\text { Unifocal, } \\
\text { temporal }\end{array}$ & & $\begin{array}{l}\text { Total brain } \\
4000 \mathrm{rad} / 5 \mathrm{wk} \\
6 \mathrm{mV}\end{array}$ \\
\hline $8 \mathrm{M} 59$ & Multiple & + & $\begin{array}{l}\text { Total brain } \\
4000 \mathrm{rad} / 4 \frac{1}{2} \mathrm{wk} \\
25 \mathrm{mV}\end{array}$ \\
\hline $9 \mathrm{~F} 56$ & $\begin{array}{l}\text { Unifocal, } \\
\text { tempero-parietal }\end{array}$ & + & $\begin{array}{l}\text { Brain and cord } \\
4000 \mathrm{rad} / 4 \frac{1}{2} \mathrm{wk} \mathrm{resp} . \\
2550 \mathrm{rad} / 4 \mathrm{wk} \\
6 \mathrm{mV}\end{array}$ \\
\hline $10 F 49$ & Multiple & & $\begin{array}{l}\text { Brain and cord } \\
4000 \mathrm{rad} / 4 \frac{1}{2} \mathrm{wk} \mathrm{resp} . \\
3000 \mathrm{rad} / 4 \frac{1}{2} \mathrm{wk} \\
6 \mathrm{mV}\end{array}$ \\
\hline $11 \times 47$ & Multiple & + & $\begin{array}{l}\text { Brain and cord } \\
4500 \mathrm{rad} / 6 \frac{1}{2} \mathrm{wk} \mathrm{resp} . \\
3300 \mathrm{rad} / 6 \mathrm{wk} \\
6 \mathrm{mV}\end{array}$ \\
\hline $12 \mathrm{M} 64$ & Multiple & & $\begin{array}{l}\text { Brain and cord } \\
4000 \mathrm{rad} / 4 \mathrm{wk} \mathrm{resp.} \\
3150 \mathrm{rad} / 3 \frac{1}{2} \mathrm{wk} \\
6 \mathrm{mV}\end{array}$ \\
\hline
\end{tabular}




\begin{tabular}{|c|c|c|}
\hline $\begin{array}{l}\text { Initial } \\
\text { response }\end{array}$ & Follow-up & $\begin{array}{l}\text { Survival } \\
\text { (months) }\end{array}$ \\
\hline++ & $\begin{array}{l}\text { Focal seizures; fairly well for } \\
39 \text { months; then steady deterioration } \\
\text { with paresis }\end{array}$ & 41 \\
\hline++ & $\begin{array}{l}\text { Fairly well during } 4 \text { months; then } \\
\text { behaviour changes; aggressiveness } \\
\text { and general disorientation }\end{array}$ & 6 \\
\hline++ & $\begin{array}{l}\text { Headaches and giddiness; progressive } \\
\text { deterioration after } 3 \text { months; } \\
\text { cerebellar pressure cone }\end{array}$ & 4 \\
\hline++ & $\begin{array}{l}\text { After } 2 \text { months progressive stupor } \\
\text { and coma; brain stem involvement }\end{array}$ & 3 \\
\hline++ & $\begin{array}{l}\text { Improved initially; after } 4 \text { months } \\
\text { symptoms of increased intracranial } \\
\text { pressure }\end{array}$ & 7 \\
\hline+++ & $\begin{array}{l}\text { Almost complete recovery; after } \\
3 \text { months forgetful, disorientation } \\
\text { and dysarthria }\end{array}$ & 5 \\
\hline++ & $\begin{array}{l}\text { Remained slightly apathetic; gait } \\
\text { disturbances; after } 24 \text { months spinal } \\
\text { cord relapse and disorientation; some } \\
\text { improvement on dexamethasone }\end{array}$ & 25 \\
\hline++ & $\begin{array}{l}\text { After } 4 \text { months cord lesion with paresis } \\
\text { right leg; positive CSF cytology; } \\
\text { radiotherapy entire cord; remissions } \\
\text { and exacerbations for another } 11 \text { months; } \\
\text { meningitis sarcomatosa }\end{array}$ & 15 \\
\hline+++ & $\begin{array}{l}\text { Slight headache and dizziness: } \\
\text { remained well until end of observation } \\
\text { period }\end{array}$ & 36 (alive, NED) \\
\hline+++ & $\begin{array}{l}\text { Residual paresis and headache; after } \\
23 \text { months apathy; CT-scan: diffuse } \\
\text { brain involvement; "strange" cells in } \\
\text { CSF; improved on dexamethasone; } \\
\text { post-radiation effect? }\end{array}$ & 35 (alive) \\
\hline+++ & $\begin{array}{l}\text { Steady improvement; after } 12 \text { months } \\
\text { sudden downhill course; confusion } \\
\text { and dysarthria }\end{array}$ & 13 \\
\hline+ & $\begin{array}{l}\text { Poor response; gradual deterioration; } \\
\text { removal of infected bone flap and } \\
\text { evacuation of epidural empyema after } \\
13 \text { months }\end{array}$ & 16 \\
\hline
\end{tabular}


Table 2. Clinical findings at time of diagnosis

\begin{tabular}{lc}
\hline $\begin{array}{l}\text { Increased intracranial pressure } \\
\text { (headache, nausea, vomiting, ctc.) }\end{array}$ & 7 cases \\
Neurologic features & 11 cases \\
$\quad$ (cranial nerve involvement, & \\
impairment of motor and sensory & \\
functions, gait disturbances, reflex & \\
abnormalitics, scizures, etc.) & \\
Impaircd higher cortical functions & 7 cases \\
(reduced level of consciousness, & \\
psychiatric manifestations, etc.) & \\
\hline
\end{tabular}

Table 3. CIassification according to Rappaport, Kiel and Lukes/Collins

\begin{tabular}{|c|c|c|c|}
\hline $\begin{array}{l}\text { Paticnt } \\
\text { No. }\end{array}$ & Rappaport & Kicl & Lukes/Collins \\
\hline 4 & $\begin{array}{l}\text { Malignant lymphoma (M.L.) } \\
\text { diffuse histiocytic, } \\
\text { poorly differentiated }\end{array}$ & $\begin{array}{l}\text { Immunoblastic } \\
\text { sarcoma }\end{array}$ & $\begin{array}{l}\text { Immunoblastic } \\
\text { sarcoma }\end{array}$ \\
\hline 7 & $\begin{array}{l}\text { M.L. diffuse lymphocytic, } \\
\text { poorly differentiated }\end{array}$ & $\begin{array}{l}\text { Lymphoblastic } \\
\text { sarcoma }\end{array}$ & $\begin{array}{l}\text { M.L. } \\
\text { unclassifiable }\end{array}$ \\
\hline 8 & $\begin{array}{l}\text { M.L. lymphocytic, } \\
\text { (cytol.) poorly differentiated }\end{array}$ & $\begin{array}{l}\text { Lymphoblastic } \\
\text { sarcoma }\end{array}$ & $\begin{array}{l}\text { M.L. } \\
\text { unclassifiable }\end{array}$ \\
\hline 9 & $\begin{array}{l}\text { M.L. histiocytic, } \\
\text { (cytol.) poorly differentiated }\end{array}$ & $\begin{array}{l}\text { Immunoblastic } \\
\text { sarcoma }\end{array}$ & $\begin{array}{l}\text { Immunoblastic } \\
\text { sarcoma }\end{array}$ \\
\hline 10 & $\begin{array}{l}\text { M.L. diffuse lymphocytic, } \\
\text { poorly differentiated, } \\
\text { some plasmacytoid } \\
\text { differentiation }\end{array}$ & $\begin{array}{l}\text { Immunoblastic } \\
\text { sarcoma }\end{array}$ & $\begin{array}{l}\text { Immunoblastic } \\
\text { sarcoma }\end{array}$ \\
\hline 12 & $\begin{array}{l}\text { M.L. diffuse lymphocytic, } \\
\text { poorly differentiated }\end{array}$ & $\begin{array}{l}\text { Lymphoblastic } \\
\text { sarcoma }\end{array}$ & $\begin{array}{l}\text { M.L. } \\
\text { unclassifiable }\end{array}$ \\
\hline
\end{tabular}

Table 4. Survival (in months after the start of radiation therapy) according to treated area

\begin{tabular}{lccc}
\hline & \multicolumn{4}{c}{ Irradiated area } \\
& $\begin{array}{c}\text { Tumour } \\
\text { region only }\end{array}$ & $\begin{array}{c}\text { Whole } \\
\text { brain }\end{array}$ & $\begin{array}{c}\text { Brain and } \\
\text { cord }\end{array}$ \\
\hline Survival & 4 & 3 & 13 \\
(months) & 6 & 5 & 16 \\
& 41 & 7 & $35^{+}$ \\
& & 15 & $36^{+}$NED \\
\hline
\end{tabular}

data suggest that patients with cerebral lymphomas run a high risk of cord involvement.

Most authors agree on the essential role of radiotherapy in the management of the CNS lymphomas. Treatment of the whole brain is recommended as the safest approach. Prophylactic irradiation to the spinal axis is usually advocated only in selected cases [5, 7]. However, selection of patients at risk, based on routine investigations or histology, appears very difficult, if not impossible. CSF cytology reports are not always available. Hence, after careful scrutiny of the literature, we suggest that treatment modalities should include the entire GNS. Our limited material does not convincingly support this theory, but there are definite indications that whole CNS irradiation improves the prognosis. Taylor et al. [4] also inferred that total craniospinal radiation therapy appears to be indicated. Uncertainties remain about the optimal dosage schedules. In our institute the brain is irradiated with $4000-4500$ rad midplane in $4-4 \frac{1}{2}$ weeks, whereas prophylactic cord irradiation amounts to $3000-3300 \mathrm{rad}$ at $\pm 6 \mathrm{~cm}$ in $4-4 \frac{1}{2}$ weeks. The head is fixed by means of a cast and special care is taken in order to include the entire base of the skull in the radiation fields. If the primary location is in the cord, this area should receive a higher dose. Littman and Wang [7] advocate a minimum dose of $4500 \mathrm{rad}$ at $1000 \mathrm{rad}$ per week to the whole brain, with a booster dose of 500-1000 rad to any residual tumour. We fecl reluctant to alter our current radiotherapy policy to this rather aggressive approach, because of its increased risk of radiation induced encephalopathy. 
Table 5. Treatment and survival according to site of involvement

\begin{tabular}{lccc}
\hline & \multicolumn{1}{c}{$\begin{array}{c}\text { Irradiated area } \\
\text { Partial CNS } \\
\text { (tumour region only; } \\
\text { whole brain) }\end{array}$} & $\begin{array}{c}\text { Entire CNS } \\
\text { (brain and } \\
\text { cord) }\end{array}$ \\
\hline $\begin{array}{l}\text { Site of } \\
\text { involvement }\end{array}$ & Favourable & Unfavourable & Unfavourable \\
\hline $\begin{array}{l}\text { Survival } \\
\text { (months) }\end{array}$ & 5 & 3 & 13 \\
& 25 & 4 & 16 \\
& 41 & 6 & $35^{+}$ \\
& & 7 & $36^{+}$NED \\
\hline
\end{tabular}

Alternatively, for prophylactic treatment of the cord, intrathecal administration of cytostatic drugs might also be of value. The advantage of this treatment is its marrow sparing properties, although extraneural spread of the primary cerebral non-Hodgkin's lymphomas appears very rare and the need for systemic chemotherapy in a later stage of the disease is probably negligible. On the other hand, prolonged survivals after entire CNS irradiation may prove responsible for a higher incidence of extraneural involvement in future series. Whether one of these two approaches-entire CNS irradiation vs brain irradiation with intrathecal chemotherapy-shows any superiority awaits further elucidation.

\section{REFERENGES}

1. C. Freeman, J. W. Berg and S. J. Cutler, Occurrence and prognosis of extranodal lymphomas. Cancer (Philad.) 29, 252 (1972).

2. S. Stefanko and D. Moffie, Primary reticulum-cell sarcoma of the brain; a clinical-pathological study. Clin. Neurol. Neurosurg. 77, 96 (1974).

3. J. M. Henry, R. R. Heffner, S. H. Dillard, K. M. Earle and R. L. Davis, Primary malignant lymphomas of the central nervous system. Cancer (Philad.) 34, $1293(1974)$.

4. C. R. Taylor, R. Russell, R. J. Lukes and R. L. Davis, An immunohistological study of immunoglobulin content of primary central nervous system lymphomas. Cancer (Philad.) 41, 2197 (1978).

5. R. H. Sagerman, J. R. Cassady and C. H. Chang, Radiation therapy for intracranial lymphoma. Radiology 88, 552 (1967).

6. K. Jellinger, T. Radaskiewicz and F. Slowik, Primary malignant lymphomas of the central nervous system in man. Acta neuropath. (Berl.) Suppl. VI, 95 (1975).

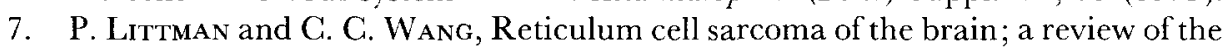
literature and a study of 19 cases. Cancer (Philad.) 35, 1412 (1975).

8. I. Penn, The incidence of malignancies in transplant recipients. Transpl. Proc. 7, 323 (1975).

9. H. Rappaport, Tumors of the hematopoietic system. In Atlas of Tumor Pathology. Washington Armed Forces Institute of Pathology, Section III Fascicle 8, p. 91 (1966).

10. R. Gerard-Marchant, I. Haylin, K. Lennert, F. Rilke, A. G. Stansfeld and J. A. M. van UNNIK, Classification of non-Hodgkin's lymphomas. Lancet ii, 406 (1974).

11. R. J. Lukes and R. D. Collins, A functional approach to the classification of malignant lymphoma. In Diagnosis and Therapy of Malignant Lymphoma. Recent Results in Cancer Research (Edited by K. Musshoff), Vol. 46, p. 18, Springer. Berlin (1974).

12. D. R. Enzmann, J. Krikorian, D. Norman, R. Kramer, J. Pollock and M. Faer, Computed tomography in primary reticulum cell sarcoma of the brain. Radiology 130, 165 (1979).

13. J. H. Adams, The classification of microgliomatosis with particular reference to diffuse microgliomatosis. Acta neuropath. (Berl.). Suppl. VI, 119 (1975).

14. M. RezNik, Réticulosarcome primitif du système nerveux central. Acta neurol. belg. 76, 227 (1976). 
15. H. H. Schaumburg, C. R. Plank and R. D. Adams, The reticulum cell sarcomamicroglioma group of brain tumours; a consideration of their clinical features and therapy. Brain 95, 199 (1972).

16. R. O. BARNARD and T. SCOTt, Pattern of proliferation in cerebral lymphoreticular tumours. Acta neuropath. (Berl.) Suppl. VI, 125 (1975).

17. A. A. Miller and F. Ramsden, Primary reticulosis of the central nervous system; microgliomatosis. Acta neurochir. (Wien) 11, 439 (1964).

18. J. R. Lehrich, E. P. Richardson and G. M. Kleinman, Abulia, paraparesis and left-sided blindness in a 66-year old woman. New Engl. 7. Med. 299, 1349 (1978). 